\title{
Synthesis and Characterization of Mixed Ligand Complexes with Ethyl - $\alpha$ - Isonitrosoacetoacetate and Dienes
}

\author{
ANITA TAKSANDE* R. D. RAUT ${ }^{\mathrm{a}}$ M. D. CHOUDHARY ${ }^{\mathrm{b}}$ and N.N. BHOLE ${ }^{\mathrm{b}}$

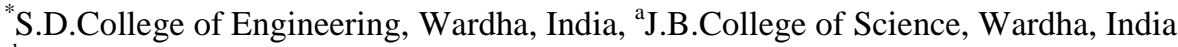 \\ ${ }^{\mathrm{b}}$ B.D.College of Engineering, Wardha, India \\ anitataksande@gmail.com
}

Received 23 May 2012 / Accepted 20 June 2012

\begin{abstract}
Mixed ligand $\mathrm{Co}(\mathrm{II}), \mathrm{Ni}(\mathrm{II})$ and $\mathrm{Cu}(\mathrm{II})$ complexes $\mathrm{Co}(\mathrm{EINA})_{2}(\mathrm{PPD}), \mathrm{Ni}(\mathrm{EINA})_{2}(\mathrm{PPD})$ and $\mathrm{Cu}(\mathrm{EINA})_{2}$ (PPD), formed with ethyl- $\alpha$-isonitrosoacetoacetate and dienes have been synthesized and characterized by their elemental analysis, infra red spectra and magnetic measurements. Ethyl- $\alpha$ isonitrosoacetoacetate shows a tridentate behavior with coordination occurring through two oximino nitrogen atoms and further two coordination sides of metal ion are satisfied by oxygen atom. Diene acts as a bidentate ligand coordinating through the two nitrogen of the amino group.
\end{abstract}

Keywords: Synthesis, characterization, $\mathrm{Co}(\mathrm{II}), \mathrm{Cu}(\mathrm{II})$ and Ni(II), Ethyl- $\alpha$-isonitrosoacetoacetate, Dienes

\section{Introduction}

The role of mixed ligand complexes in biological systems is well known ${ }^{1}$. Synthesis and charecterization of some bivalent simple metal complexes of isonitrosoacetophenon have been reported ${ }^{2-5}$. Ethyl- $\alpha$-isonitrosoacetoacetate (EINA) is bidentate ligand containing two corboxylate groups and $\mathrm{NH}$ group. It can coordinate with the metal ion through the only two oximino nitrogen atom acting as a bidentate ligand. It also coordinate through the corboxylate oxygen atom and the nitrogen of the amino group and thus acts as a bidentate ligand. Complexes of $\mathrm{Co}(\mathrm{II}), \mathrm{Ni}(\mathrm{II})$ and $\mathrm{Cu}(\mathrm{II})$ of diamidediimine macrocyles ${ }^{6}$ and mixed ligand complexes of $\mathrm{Co}(\mathrm{II})$ and $\mathrm{Cu}(\mathrm{II})$ has been reported ${ }^{7}$. The present paper outlines the synthesis and characterization of mixed ligand complexes formed with ethyl- $\alpha$ isonitrosoacetoacetate and $p$-phenylenediamine (PPD).

\section{Experimental}

All the chemicals used were of analytical grade.

\section{Preparation of mixed ligand complexes}

A warm ethanolic solution of metal salts $(0.01 \mathrm{M})$ was added to ethanalic solution of ligand $(0.02 \mathrm{M})$ and $p$-phenylenediamine $(0.01 \mathrm{M})$. The resulting solution was refluxed for about six 
hours. The complex thus formed was filtered and washed with alcohol and dried in vacuum over fused $\mathrm{CaCl}_{2}$. The metal estimation was carried out by standard method and nitrogen by Kjeldahl method. The conductance was measured in DMF and DMSO solvent on and Elico CM-82 Conductivity Bridge. The magnetic susceptibility measurement at room temperature was made on Gouy's balance. The IR spectra were recorded on Perkin-Elmer-137 instrument in Nujol mull/KBr pellets ${ }^{1} \mathrm{H}$ NMR spectra were recorded on a Bruker WP 80 SY spectrometer.

\section{Results and Discussion}

The elemental analysis shown in Table 1 indicates that all the metal complexes have 1:2 stoichiometry and are dark colour substances, soluble in DMF and DMSO. The molar conductance values obtained for these complexes at the concentration of $10^{-3}$ are in the range of 2.9 to $1.07 \mathrm{ohm}^{-1} \mathrm{mo} 1 \mathrm{~cm}^{2}$. These values are too low to account for any dissociation of the complexes can be regarded as non-electrolytes. The magnetic moment values for $\mathrm{Cu}(\mathrm{II})$ complexes are in the range of $1.58 \mathrm{BM}$, Ni(II) complexes 2.46 BM and $\mathrm{Co}(\mathrm{II}) 4.28 \mathrm{BM}$ having octahedral structure.

Table 1. Elemental analysis and magnetic moment of the complexes

\begin{tabular}{|c|c|c|c|c|c|c|c|}
\hline \multirow{2}{*}{$\begin{array}{l}0 \\
\dot{z} \\
\dot{0}\end{array}$} & \multirow{2}{*}{$\begin{array}{l}\text { Empirical } \\
\text { formula }\end{array}$} & $\begin{array}{l}\% \text { of } \\
\text { Carbon }\end{array}$ & $\begin{array}{c}\% \text { of } \\
\text { Hydrogen }\end{array}$ & $\begin{array}{c}\% \text { of } \\
\text { Nitrogen }\end{array}$ & $\begin{array}{l}\% \text { of } \\
\text { Metal }\end{array}$ & \multirow{2}{*}{\multicolumn{2}{|c|}{$\begin{array}{l}\text { Molar conductance concentratior } \\
-\quad 10^{-3} \\
\text { Magnetic moment } \mu \mathrm{BM}\end{array}$}} \\
\hline & & $\begin{array}{l}\text { Found } \\
\text { Calc. }\end{array}$ & $\begin{array}{l}\text { Found } \\
\text { Calc. }\end{array}$ & $\begin{array}{l}\text { Found } \\
\text { Calc. }\end{array}$ & $\begin{array}{l}\text { Found } \\
\text { Calc. }\end{array}$ & & \\
\hline 1 & $\begin{array}{l}\mathrm{Cu}(\mathrm{EINA})_{2} \\
\text { (PPD) }\end{array}$ & $\begin{array}{c}44.35 \\
(44.30)\end{array}$ & $\begin{array}{c}5.40 \\
(5.33)\end{array}$ & $\begin{array}{c}11.50 \\
(11.48)\end{array}$ & $\begin{array}{c}13.30 \\
(13.33)\end{array}$ & 1.07 & 1.58 \\
\hline 2 & $\begin{array}{l}\mathrm{Ni}(\mathrm{EINA})_{2} \\
\text { (PPD) }\end{array}$ & $\begin{array}{c}44.80 \\
(44.72)\end{array}$ & $\begin{array}{c}5.45 \\
(5.38)\end{array}$ & $\begin{array}{c}11.62 \\
(11.59)\end{array}$ & $\begin{array}{c}12.25 \\
(12.20)\end{array}$ & 1.87 & 2.46 \\
\hline 3 & $\begin{array}{c}\mathrm{Co}(\mathrm{EINA})_{2} \\
(\mathrm{PPD})\end{array}$ & $\begin{array}{c}44.70 \\
(44.74) \\
\end{array}$ & $\begin{array}{c}5.42 \\
(5.38)\end{array}$ & $\begin{array}{c}11.62 \\
(11.60)\end{array}$ & $\begin{array}{c}12.18 \\
(12.15)\end{array}$ & 2.9 & 4.28 \\
\hline
\end{tabular}

The infrared spectra of HEINA, PPD and its metal complexes with Co(II), Ni(II) and $\mathrm{Cu}(\mathrm{II})$ have been recorded. And the significant infra red bands are summarized in Table 2 . Coordination sites of the HEINA, PPD have been determined by careful comparison of infra red spectra of the complexes. The infra red spectra of HEINA and PPD gave a strong band at $3410 \mathrm{~cm}^{-1}$ which may be assigned to $\mathrm{OH}$ and $\mathrm{N}-\mathrm{OH}$ group. Which was absent in metal complexes.

Table 2. Significant infra red bands

\begin{tabular}{ccccc}
\hline Assignments & HEINA & Ni(EINA) ${ }_{2}$ PPD & CO(EINA) $)_{2}$ PPD & Cu(EINA) $)_{2}$ PPD \\
\hline Ar-H & 3250 & 3218 & 3220 & 3224 \\
OH \&N-OH & 3410 & ------- & 3220 \\
$-\mathrm{O}-\mathrm{H}$ & ---- & 3216 & 3326 & ---- \\
$\mathrm{C}=\mathrm{O}$ & 1620 & ---- & ---- & 1610 \\
$\mathrm{C}=\mathrm{N}$ & ---- & 1590 & 1604 & 1170 \\
$\mathrm{CH}_{3}$ & 1190 & 1168 & 1200 & \\
\hline
\end{tabular}

The infra red spectra of HEINA gave a strong band at $1620 \mathrm{~cm}^{-1}$ which may be attributed to the ester $\mathrm{C}=\mathrm{O}$. The infra red spectra of metal complexes gave two new band at $3216 \mathrm{~cm}^{-1}$ and $1590 \mathrm{~cm}^{-1}$ which is due to $\mathrm{O}-\mathrm{H}$ and $-\mathrm{C}=\mathrm{N}$ group take part in coordination of ligand. 
The strong band due to $v \mathrm{C}=\mathrm{O}$ seen at $1620 \mathrm{~cm}^{-1}$ in (HEINA) (PPD) is absent in all the complexes indicating a successful attachment of carboxyl oxygen to metal ion. The $v \mathrm{C}=\mathrm{N}$ band appear in the 1590-1628/cm reason for metal complexes of (HEINA) (PPD) while ligand frequency for $v \mathrm{C}=\mathrm{N}$ band appear at $1610 / \mathrm{cm}$ shift of the band towards the low frequency region indicates wider delocalization of the electric charge in the newly form chelate ring. This also suggest the strong bonding of $v \mathrm{C}=\mathrm{N}$ group with the metal in coordination.

\section{References}

1. Sigel H, Metal, Ions in Biological Systems, Mixed ligand complexes, Dekker M, New York Chapter I, Vol. 2, 1973.

2. $\quad$ Natrajan C and Hussain A N, Indian J Chem., 1983, 22A, 527.

3. Talwar U B and Halder B C, J Inorg Nucl Chem., 1970, 32, 213-220.

4. Prakash D, Singh B P and Gupta O P, Vijnana Parishad Anusandhan Patrika, 1992, 35(4), 305.

5. Banerjee A K, Layten A J, Nyholm R S and Truter M R, J Chem Soc., 1970, 292A, 18-84

6. $\quad$ Ahmed A A, BenGuzzi S A and Hadi A A, J Sci Appl., 2007, 79.

7. Singh Mahesh K, Das Arijit and Paul Bijaya, J Coord Chem., 2009, 62(16), 2745-2754. 